\title{
Treatment of Adult Intussusception with Non-operative Management: A case report
}

\author{
Shahrul Rahman', Muhammad Al Anas ${ }^{2}$ \\ ${ }^{1}$ Department of Internal Medicine, Faculty of Medicine, University of Muhammadiyah Sumatera Utara, \\ Medan, Indonesia \\ ${ }^{2}$ Faculty of Medicine, University of Muhammadiyah Sumatera Utara, Medan, Indonesia \\ Correspondence email: shahrulrahman@umsu.ac.id
}

\begin{abstract}
Intussusceptions, defined as insertion of proximal part of intestine into distal one, it is the second most common acute abdomen pathology after appendicitis. Acute intussusception is one of the common causes of acute intestinal obstruction in children, but on seldom occasions associated with leading points to the intussusceptions. The symptoms are the result of intussusception, like intestinal obstruction, volvulus due to subserosa lipoma and hemorrhage due to ulcerations of the overlying mucosa caused by direct pressure from the lipoma or the intussusception itself. Intussusception in adults is very rare. Most intussusception cases must be treated surgically. In patients who present with a vague history and constellation of abdominal symptoms pointing towards obstruction and are found to have a short segment intussusception, it is a valid option to apply a conservative approach with caution. Based on the available literature, CT scan evaluation seems to have both diagnostic and prognostic value, as it provides enough evidence with regards to signs indicating the need for surgery. Herewith, we describe a rare case of intussusception in Indonesian adult which was successfully treated non-surgically.
\end{abstract}

Keywords : intussusception, obstruction, non-surgically

\section{INTRODUCTION}

Intussusceptions, defined as insertion of proximal part of intestine into distal one, it is the second most common acute abdomen pathology after appendicitis. ${ }^{1}$ Acute intussusception is one of the common causes of acute intestinal obstruction in children, but on seldom occasions associated with leading points to the intussusceptions. While chronic intussusceptions, which usually has history of more than 14 days, ${ }^{2}$ is rare in childhood, commonly associated with leading points as neoplasm and other pathology. ${ }^{3}$ It is rare to find the triad of acute intussusceptions, colicky intermittent abdominal pain, vomiting, and bloody stool in chronic intussusceptions. 4

Acute intussusceptions as a clinical entity is poorly recognized and rarely included in the differential diagnosis of 
prolonged abdominal symptoms and faltering growth as reported in some studies. $^{4}$ It is frequently associated with a high rate of unsuccessful hydrostatic reductions. This makes an early surgical intervention advisable. ${ }^{5}$

$$
\text { Most pediatric ileocolic }
$$

intussusceptions are idiopathic. In adults and occasionally in children over 2 years of age, a pathologic lead point for intussusception can be found. ${ }^{2}$ In children, the incidence of identifiable lead point in pediatric intussusception has been reported as 1.5$12.0 \%$. Underlying pathological causes of intussusception can be identified in 1.5$12.0 \%$ of cases. ${ }^{6}$ These include Meckel's diverticulum, polyps, duplications, mesentery cysts, intestinal hematoma and lymphoma. $^{7}$

As stated above, the management of intussusception in general is to perform surgery. We report this case because of the successful non-surgical management of intussusception. Herewith, we describe a rare case of intussusception in Indonesian adult reported.

\section{CASE}

A 32-year-old man presented with acute abdominal pain for three days at a general hospital. He also complained nausea, and vomiting for a week. The patient had no fever, no change in stool frequency and consistencies, or any other illnesses. He only consumed prescribed medication from hospital to treat the pain.

On physical examination, we found a normo-weight patient with normal vital signs. Beside mild epigastric pain on palpation, the increase peristaltic in auscultation was found. The rest of his

Buletin Farmatera

Fakultas Kedokteran (FK)

Universitas Muhammadiyah Sumatera Utara (UMSU)

http://jurnal.umsu.ac.id/index.php/buletin_farmatera physical examination showed no abnormalities.

The patient was treated with intravenous administration of a sorbitol solution30-drips/minute and proton-pump inhibitor injection (lansoprazole $30 \mathrm{mg} / \mathrm{day}$ ).

The following investigations were performed: laboratory findings showed increased leukocytes of $12.71 \times 10^{3} / \mathrm{uL}$, monocytes of $10 \%$ and low lymphocytes of $17.39 \%$. He had a normal renal function. Electrolyte test was normal. The plain abdominal $\mathrm{x}$-ray showed an abdominal distension by increased air distribution in intestine, and air fluid level showed. We can concluded the case as ileus buy using the plain abdominal X-ray (Figure 1).

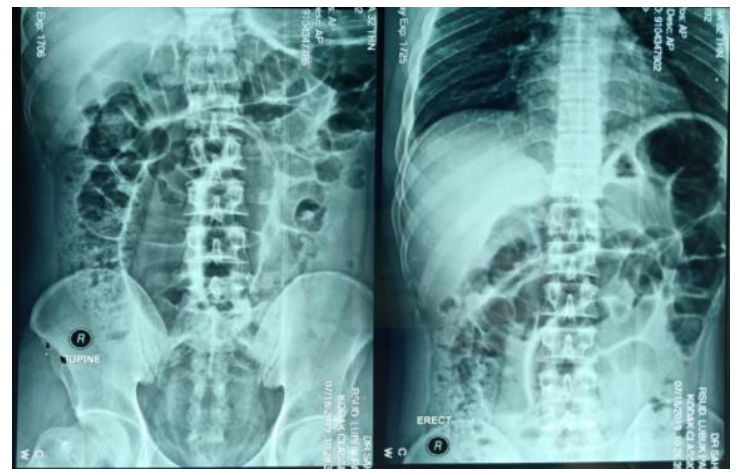

Figure 1. Plain abdominal x-ray shows an abdominal distension by increased air distribution in intestine, and air fluid level showed.

We added amino acids in dextrose solution for intravenous infusion 1000 $\mathrm{mL} / 24$ hour by turns with sorbitol solutions. We also replaced proton-pump inhibitor injection with histamine H2-receptor antagonist injection (ranitidine $50 \mathrm{mg} / 12$ hours). We also added metoclopramide injection $10 \mathrm{mg} / 24$ hours. Patient received injection of intravenous antibiotics with ceftriaxone $1 \mathrm{gr} / 24$ hours, and steroids with dexamethasone injection $5 \mathrm{mg} / 24$ hours. 
We decided to perform a computed tomography (CT) scan of the abdomen with contrast. In order to perform the procedure, the patients were given bowel preparation. The CT scan were performed in the second day of hospitalization while after the procedure, the treatments were continued. The CT scan was performed in second day, and the result showed mild liver enlargement with sharp edges, and in colon area there was increased distribution of air.

The patient was free of all the original symptoms by the fifth day after hospitalization. After that, the patient was able to return back home.

\section{DISCUSSION}

Intussusception in adults is very rare with an incidence of two to three cases per population of $1,000,000$ per year. ${ }^{8}$ When it is found in adults, the cause is usually secondary to a pathologic lead point within the bowel due to altered normal peristaltic movements. ${ }^{9}$

The limitation in this report is we didn't further perform an examination to find the cause. Lipomasare more common in the colon $(75 \%)$ than in the small intestine $(<25 \%)$. They are the second most common benign small bowel tumors after leiomyomas. Their usual localization in the small bowel is the ileum in $50 \%$ of the cases. The peak age of disease is in the sixth to seventh decade of life. They originate in the submucosa in $90 \%$ of the cases and usually are solitary $(85 \%-89 \%)$. Size may range from 1 to $30 \mathrm{~cm}$. Usually, asymptomatic but they can give rise to symptoms related to their size and localization. A total of $75 \%$ of those greater than $4 \mathrm{~cm}$ are symptomatic. ${ }^{10,11}$

Buletin Farmatera

Fakultas Kedokteran (FK)

Universitas Muhammadiyah Sumatera Utara (UMSU)

http://jurnal.umsu.ac.id/index.php/buletin_farmatera
The symptoms are the result of intussusception, such as intestinal obstruction, volvulus due to subserosa lipoma and hemorrhage due to ulcerations of the overlying mucosa caused by direct pressure from the lipoma or the intussusception itself. $^{12}$ In contrast to the acute presentation of childhood intussusception, the adult type usually has a subacute or chronic onset. Less than $20 \%$ present with acute bowel obstruction.

A palpable abdominal mass is present in only $7 \%-42 \%$ of the cases. ${ }^{13}$ Intermittent intussusception due to the lipoma may cause non-specific symptoms and carry a further challenge for diagnosis.

In adults, intussusception usually presents with intermittent abdominal pain, nausea, vomiting, constipation, melena or even weight loss. In our case report, the patient had a very mild clinical symptoms. The laboratory findings showed an increased level of leukocytes and our patient also described similar unspecific symptoms. In the literature, occult hemorrhage and intermittent intussusceptions are the most frequent clinical findings. ${ }^{13,14}$

The psychiatric background of the patient in our case report made the interpretation of the clinical findings difficult and might delay the diagnostic tests. The information of colic pain and altered stool, the presence of appetite but fear of eating because of vomiting, pain and the anemia were reasons for the CT of the abdomen for further examination. Preoperative diagnosis is difficult due to the variability of the clinical presentation. CT scan is the imaging of choice radiological finding is a mass lesion, representing a thickened segment of the bowel and the tumor with low density equal to fat. CT scan

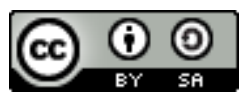


can also give indirect signs of bowel ischemia like free fluid and fluid or gas collection in the intestinal wall. CT scan has a specificity of $100 \%$ and sensitivity of up to $87 \%$ in adults. ${ }^{15}$

In our case, CT scan showed the atypical characteristics of invagination with no further complications after the medicaments were given. The localization of intussusception in the gastrointestinal tract is also important: colo-colonic intussusception is $>70 \%$ caused by a malignancy. ${ }^{10,11}$ Neoplasia is also a leading lesion in $57 \%$ in the small bowel but malignancy here is less frequent $(30 \%)$. Seventy percent of adult small intestine intussusception is caused by benign entities. ${ }^{13}$ In our case report, the fatty lesion was located in the terminal ileum. No pathologic lymph nodes were detected in the CT scan.

In the literature, there is no consensus on safety and efficacy of laparoscopy application in adult intususception. ${ }^{16}$ In the present case, we selected non-operative managements for the following reasons: the patients clinical condition was good. Clinically and radiologically, the bowel was not distended too much so that an observation and non-operative approach was still possible and safe. There were no signs of ischemia of the bowel segment. Except an open appendectomy, patient did not undergo previous surgery; thus, the possibility of intra-abdominal adhesions was low. Intraoperatively, the affected bowel segment of our patients appeared short with a mild image of an ileus. There are other case reports described that an open surgery was necessary because preoperative findings suggested the necessity of large resection such as hemicolectomy. ${ }^{16}$

Buletin Farmatera

Fakultas Kedokteran (FK)

Universitas Muhammadiyah Sumatera Utara (UMSU)

http://jurnal.umsu.ac.id/index.php/buletin_farmatera
All patients need to be observed for progression or regression of their clinical pictures in order to avoid potential complications such as ischemia, and potential necrosis of the affected bowel segment. For patients presenting a vague clinical picture and symptoms at the time of admission, short intussusception length on imaging studies, simultaneous nature of intussusceptions in different locations, and the absence of a lead point in the pathogenesis based on follow-up imaging studies, conservative management is appropriate, albeit with caution. If the patients had developed signs of obstruction, bowel ischemia or necrosis, exploratory surgery is indicated. ${ }^{17,18}$

\section{CONCLUSION}

In patients who present with a vague history and constellation of abdominal symptoms pointing towards obstruction and are found to have a short segment intussusception, it is a valid option to apply a conservative approach with caution. Based on the available literature, CT evaluation seems to have both diagnostic and prognostic value, as it provides enough evidence with regards to signs indicating the need for surgery.

If exam and CT findings, as described earlier, hint or point towards a self-limiting intussusception, then conservative management with caution is appropriate with serial abdominal exams, bowel rest, IV fluids, and appropriate labs on an as needed basis, along with a follow-up imaging studies to assess the etiology and the status of the intussusceptions. In recurrent cases, further GI evaluation is warranted.

With this conservative approach and in the light of absence of evidence of other

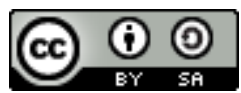


coexisting pathologies, an emergent laparotomy can be avoided. In equivocal cases, diagnostic laparoscopy can assist indecision making, surgical planning, and treatment.

\section{REFERENCES}

1. Korkmaz M, Yazgan H, Budan K, Korkmaz F, Keles E, Gebesce A, Demirdöven M, Etlik Ö. Pneumatic reduction in the treatment of childhood intussusception cases. Gaziantep Medical Journal. 2012; 18(2): 56-60.

2. Marsicovetere P, Ivatury SJ, White B, Holubar SD. Intestinal Intussusception: Etiology, Diagnosis, and Treatment. Clin Colon Rectal Surg. 2017 Feb; 30(1): 30-39

3. Choi SH, Han SA, Won KY. Chronic Intussusception caused by diffuse large B-Cell Lymphoma in a 6-yearold girl presenting with abdominal pain and constipation for 2 Months. Journal of Korean medical science. 2016 Feb 1; 31(2): 321-5.

4. Saad AAM, Kkalid T, Abbas M, Salih KMA. Rare presentation of chronic ileocecal intussusception secondary to Burkitt's lymphoma in three years Sudanese boy: a case report and literature review. Pan Afr Med J. 2018; 31: 57.

5. Xiaolong X, Yang W, Qi W, Yiyang Z, Bong X. Risk factors for failure of hydrostatic reduction of intussusception in pediatric patients. Medicine (Baltimore). 2019 Jan; 98(1): e13826.

6. Wang SM, Huang FC, Wu CH, Ko SF, Lee SY, Hsiao CC. Ileocecal Burkitt's Lymphoma Presenting as Ileocolic Intussusception With Appendiceal

Buletin Farmatera

Fakultas Kedokteran (FK)

Universitas Muhammadiyah Sumatera Utara (UMSU)

http://jurnal.umsu.ac.id/index.php/buletin_farmatera
Invagination and Acute Appendicitis. J Formos Med Assoc 2010;109(6):476479.

7. Kotha VK, Khandelwal A, Shanboque AK, et al. Radiologist's perspective for the Meckel's diverticulum and its complications. $\mathrm{Br}$ J Radiol. 2014; 87(1037): 740-743.

8. Paramythiotis D, Goulas P, Paparavmidis T, Michalopoulos A. Bowel intussusception in adults: a report of three interesting cases and current trends for diagnosis and surgical management. Hippokratia. 2019; 23(1): 37-41.

9. Snyder CW and Cannon JA. Diffuse intestinal lipomatosis presenting as adult intussusception. World $\mathbf{J}$ Colorectal Surg 2013; 3(1): 14.

10. Uyulmaz S, Zund M, Caspar U, Diebold J, Slankamenac K. Ileoileal intussusception in unspecific recurrent abdominal pain in adult: A case report. SAGE Open Medical Case Reports 2018; Volume 6: 1-4.

11. Faulx AL, Korhart S, Acosta RD, et al. The role of endoscopy in subepithelial lesions of the GI tract. Gastrointestinal Endoscopy 2017; 8(6): 1117-1132.

12. Vagholkar K, Chavan R, Mahadik A, Maurya I. Lipoma of the Small Intestine: A Cause for Intussusception in Adults. Case Reports in Surgery 2015; 1-3.

13. Sayeed M. Benzamin M. Akter S. Mazumder MW. Karim ASMB. Dey BP. Omental Cyst - Rare Cause of Abdominal Pain in a 7-YearOld Child: A Case Report. Portuguese Journal of Gastroenterology 2020; 1-5.

14. Shimazaki J, Nakachi T, Tabuchi T, et al. Laparoscopic management of an 
octogenarian adult intussusception caused by an ileal lipoma suspected preoperatively: a case report. World J Surg Oncol 2015; 13: 75.

15. Siow SL and Mahendran HA. A case series of adult intussusception managed laparoscopically. Surg Laparosc Endosc Percutan Tech 2014; 24(4): 327-331.

16. Tartaglia D, Bertolucci A, Palmeri M, et al. The role of laparoscopy in adult bowel obstruction caused by intussusception. Ann Ital Chir 2014; 85(4): 328-331.

17. Kumar K, Noori MR, Patel KM, et al. Rare diagnosis of intestinal lipomatosis complicated by intussusception in an adult: a case report. Int J Surg Case Rep 2017; 39: 339-342.

18. Gys B, Haenen F and Gys T. Ileocolic intussusception caused by a giant ulcerating lipoma of Bauhin's valve: an unusual cause of intestinal obstruction in the adult. Indian J Surg 2015; 77(Suppl. 1): 1-2. 